УДК 37.015 .3

DOI https://doi.org/10.33989/2519-8254.2020.8.239458

ORCID 0000-0001-6096-5144

ORCID 0000-0002-0553-4277

\title{
ESSENCE, STRUCTURE AND FEATURES OF LIFELONG LEARNING COMPETENCE
}

\author{
Володимир Мироненко, \\ аспірант Полтавського національного педагогічного університету імені В. Г. Короленка; \\ Валентина Титаренко, \\ докторка педагогічних наук, професорка, декан факультету технологій та дизайну \\ Полтавського національного педагогічного університету імені В.Г. Короленка.
}

У статті розглянуто сутність, структуру та особливості компетентності людини вчитися впродовж життя. Для досягнення поставленої мети на різних етапах наукового пошуку використано комплекс взаємопов'язаних теоретичних методів - аналіз, класифікація, узагальнення теоретичних підходів вітчизняних $i$ зарубіжних науковців у галузі філософії, соиіологї, педагогіки, психології для визначення сутності, структури й особливостей компетентності вчитися впродовж життя. Метою статті обрано розкриття сутності структури та особливостей компетентності людини вчитися впродовж життя. Схарактеризовано змістову частину понять "компетентність», «навчання», «життєдіяльність людини» як провідних складових феномену «компетентність учитися впродовж життя». Дано авторське формулювання поняття «компетентність навчання впродовж життя людини» як становлення інтегративної якості особистості, що містить складові (життєва зрілість, освітня спрямованість, креативність та ініціативність у вирішенні життєвих ситуацій, високий рівень реалізації подій жсття) та сформованість самостійності особистості. Розглянуто базові рівні формування компетентності навчання впродовж життя: початковий, адаптації до умов реальної життєвої діяльності, формування індивідуального стилю освітньої діяльності та сходження до вериин професіоналізму. Доведено, щуо досягнення учнівською молоддю оптимальних рівнів життєвого розвитку відбувається внаслідок формування життєвої зрілості та самостійності особистості.

Окреслено аспекти інтеграції концептуальних і технологічних засад підготовки майбутнього вчителя трудового навчання $i$ технологій до формування в учнів компетентності вчитися впродовж життя в освітньому середовищі закладу загальної середньої освіти.

Ключові слова: учнівська молодь, освіта, компетентність, навчання впродовж життя, життева зрілість.

Problem statement. The priority area in the socio-economic, spiritual, and cultural development of Ukraine is an education, designed to ensure personal development following everyone's abilities and needs on the basis of lifelong learning, which is based on the laws of Ukraine «On Education», «On Higher Education», «National Doctrine on Education Development», «the State National Program «Education», «the Sectoral Concept of Development of Continuing Pedagogical Education», «the National Strategy for the Development of Education in Ukraine until 2021».

The effectiveness of how a person solves the tasks in the everyday life is determined by the level how well developed is the competence of lifelong learning - prognostic in nature and able to respond flexibly to social changes.

Psychological and pedagogical principles for substantiation of a holistic approach to the formation of lifelong learning competence became the works of modern scientists, whose research 
results have helped to define this phenomenon as an integrative manifestation of several components of learning related to human life.

Research and publication analysis. Issues of human development during lifetime were the subject for consideration in the psychological and pedagogical works of B. Ananiev, O. Antonova, A. Bodalov, A. Verbytsky, N. Kuzmina, O. Leontiev, V. Morgun, A. Petrovsky, V. Rybalka, S Rubinstein, and others.

Some aspects of the problem are devoted to several important studies, in particular: O. Ganzhey studied the pedagogical conditions and means of the socio-professional maturity formation of the future history teacher (Ganzha, 2011); O. Andrienko - general scientific bases for development of professional maturity of the teacher (Andrienko, 2002); several aspects of the problem are covered in the works of Y. Gilbukh, B. Gershunsky, A. Petrovsky, and other famous scientists.

At the same time, the problem of understanding the essence and structure of lifelong learning competence remains open, in particular, integration aspects of conceptual and technological principles of training future teachers of labor training to form students' lifelong learning competence in the educational environment of the general secondary education.

The purpose of the article is to reveal the essence, structure, and features of human lifelong learning competence.

To achieve this goal at different stages of scientific research we use a set of interrelated theoretical methods - analysis, classification, generalization of theoretical approaches, presented by domestic and foreign scientists in philosophy, sociology, pedagogy, psychology to determine the nature, structure, and characteristics of lifelong learning.

The results of the research. An important practical task of our study is to identify the structure and features of lifelong learning competence. During the research, it is necessary to characterize the semantic part of the concepts «competence», «learning», «human life» components as the most important parts of the phenomenon «lifelong learning competence».

A. Petrovsky sees a high level of life maturity in the active participation of the individual in a society, a developed sense of responsibility, a need to care for other people, and competently solve life problems on the way to full self-realization (Psychology. Dictionary, 1990, p. 126).

Y. Gilbukh (1994) names the life component, which combines the understanding of the relativity of the meaning of life, the predominance of the rational over the emotional, emotional balance, and prudence, as a structural component of personal maturity.

The analysis of scientific research of lifelong learning competence and legal documents in the field of education creates a basis for defining this phenomenon as a long period of ontogenesis and is due to integrative requirements and features of manifestation at the optimal level of personal life components. Content analysis of research on the structure of lifelong learning competence allows differentiating its general components by the following features that characterize a person on the following indicators: life maturity, educational orientation, creativity, and initiative in solving life situations, high level of life events realization.

The identified by us components of lifelong learning competence, defined as personal qualities, are the identification of personal qualities of the individual, which can be studied only by analyzing the life of the individual in the social environment. Only the analysis of the relationship "personality-environment" allows to objectively reveal the properties of a person as a person (Ganja, 2011, p. 18).

These components of lifelong learning competence are significant characteristics of personal maturity, which ensure the success of human life formation.

A necessary condition for the formation of lifelong learning competence defined by O. Andrienko is the development of a competence of this type, which develops at three basic levels:

1) an initial level of mastering the basics of vital knowledge in educational institutions;

2) adaptation to the conditions of real-life activity;

3 ) formation of an individual style of educational activity and the beginning of the ascent to the top of professionalism (Andrienko, 2002, pp. 31-32). 
Leading for the development of lifelong learning competence is the component of life maturity, which is determined by the focus, creativity, and initiative in solving life situations, the high level of their implementation. A condition for the successful development of life maturity of the individual is the integration of lifelong learning into one's general culture, which determines the conscious attitude to human life experience, the ability to creative perception, understanding, and transformation of the reality (Gershunsky, 2002; Psychology. Dictionary, 1990).

"The National Strategy for Education Development in Ukraine until 2021" states that the modern labor market requires from graduates not only deep theoretical knowledge but also the ability to apply it independently in non-standard, constantly changing life situations, a transition from the knowledge society to the society of life competent citizens (National Strategy for Education Development in Ukraine until 2021). This legal document regulates modernization of the structure, content, and organization of education based on the competence approach, as a strategic direction of education. Competence as the ability to productively perform professional activities is outlined by generalized and standardized ways of vital actions, which are regulated by functions important for human life (Personally oriented technologies of teaching and education in higher educational establishments, 2008).

Students' understanding that they still need to learn a lot formulates the formation of their life maturity. The formation of the subject, basic, and key competencies allow the student to see the results of educational activities. The formation of the personality will indicate a sufficient level of life maturity of the student.

Acmeological concept of education involves the holistic development of its applicants, aimed at developing the appropriate level and type of maturity at a certain stage of learning and age development of the individual (Ganja, 2011, p. 16). According to the acmeological concept of education, life maturity is understood as a characteristic of successive stages of personality formation in the process of lifelong learning. The process of forming the competence of lifelong learning should contain the three most important stages defined by modern psychology:

- adaptation as the appropriation of new social forms and values by an individual, the formation of typical patterns of behavior and activities;

- individualization as a manifestation of personality inclinations and competencies, the formation of a positive self-concept that contributes to the formation of the subject personality of a person;

- integration as the interaction of an individual and the educational environment, which stimulates one`s personal development (Psychology. Dictionary, 1990, p. 332).

Therefore, the formation of lifelong learning competence in the school period will be effective if the adaptation to the components of life through the individualization of ways to implement it before acquiring the ability to constructive interactions of personality and educational environment. The formation of lifelong learning competence of secondary school students as active actors should arise from their gradual transition from a position of being the object of educational influence to the position of being the subject of educational activity, and then - to the subject of life formation.

The process of lifelong learning competence formation is a gradual and continuous process that occurs through all the educational, professional and life activities of an individual. This process takes place in two dimensions: in the educational space of educational institutions under the control of educational, professional norms and requirements, and in the educational environment of the social surroundings, where the student must face the manifestations of a society that may not meet the norms and rules of achieving anticipated positive personal development. The Law of Ukraine "On Higher Education" proclaims the dissemination of knowledge among the population, raising the educational and cultural level of citizens as one of the main tasks of education (Law of Ukraine "On Higher Education"). In educational environment that is not completely under the control of the goals of personal maturity development, the student must constantly make an informed choice about life actions and deeds determined by the situations of living space. Considering the above-mentioned, it is necessary to view the formation of lifelong 
learning competence of student youth as a component of the development of life and professional maturity in the structure of their personal development.

Conclusions. Our analysis of legal documents in the field of education and research results on the formation of lifelong learning competence indicates the important impact of its structural components and the level of their development on the formation of future teachers' readiness for self-realization in future life. At the stage of scientific development, the interpretation of the concept of "lifelong learning" is absent in scientific encyclopedias and terminological dictionaries. Summarizing the results of the scientific research on understanding the essence of the concepts of "competence", "learning", "human life" as components of the concept of "lifelong learning competence", we concluded that students achieve optimal levels of life development due to maturity and Self-personality achievement.

The above statements are the basis for the authors to formulate the concept of lifelong learning competence of a person as a formation of an integrative quality of a personality - life maturity, which contains its components (life maturity, educational orientation, creativity, and initiative in solving life situations, high level of life events realization) and the formation of the Self-personality.

The analysis of scientific approaches regarding understanding of the essence of lifelong learning competence orients further research on this problem based on educational orientation on the gradual development of components of this competence in a specially organized educational space of educational institutions and educational environment of social surroundings.

\section{ЛIТЕРАТУРА}

Андриенко, Е. В. (2002). Психолого-педагогические основы формирования профессиональной зрелости учителя. (Дис. д-ра пед. наук). Новосибирск.

Андрущенко, В., \& Луговой, В. (Ред.). (2008). Особистісно орієнтовані технологї̈ навчання i виховання у вищих навчальних закладах. Київ: Пед. думка.

Ганжа, О. В. (2011). Формування соціально-професійної зрілості майбутнього вчителя історії у навчально-виховному середовищі. (Дис. канд. пед. наук). Кіровоград.

Гершунский, Б. С. (2002). Философия образования для XXI века. Москва: Педагог. общ-во России.

Гильбух, Ю. 3. (1994). Тест-опросник личностной зрелости. Киев: Научно-практический центр «Психодагностика и дифференцированное обучение».

Національна стратегія розвитку освіти в Украӥні на період до 2021 року. Взято 3 http://osvita.ua/legislation/other/36322/

Петровский, А. (Ред.). (1990). Психология. Словарь. Москва: Политиздат.

Про вищу освіту: Закон України. (2014). Взято з http://zakon5.rada.gov.ua/laws/show/1556-18.

\section{REFERENCES}

Andrienko, E. V. (2002). Psihologo-pedagogicheskie osnovy formirovanija professional'noj zrelosti uchitelja [Psychological and pedagogical foundations of teacher professional maturity formation]. (PhD. diss.). Novosibirsk [in Russian].

Andrushchenko, V., \& Luhovoi, V. (Eds.). (2008). Osobystisno oriientovani tekhnolohii navchannia $i$ vykhovannia $u$ vyshchykh navchalnykh zakladakh [Personally oriented technologies of teaching and education in higher educational institutions]. Kyiv: Pedahohichna dumka [in Ukrainian].

Gershunskij, B. S. (2002). Filosofija obrazovanija dlja XXI veka [Philosophy of Education for the 21st Century]. Moskva: Pedagog. obshh-vo Rossii [in Russian].

Gil'buh, Ju. Z. (1994). Test-oprosnik lichnostnoj zrelosti [Personal maturity test questionnaire]. Kiev: Nauchno-prakticheskij centr «Psihodagnostika i differencirovannoe obuchenie» [in Russian].

Hanzha, O. V. (2011). Formuvannia sotsialno-profesiinoi zrilosti maibutnoho vchytelia istorii u navchalno-vykhovnomu seredovyshchi [Formation of socio-professional maturity of the 
future history teacher in the educational environment]. (PhD diss.). Kirovohrad. [in Ukrainian].

Natsionalna stratehiia rozvytku osvity v Ukraini na period do 2021 roku [National strategy for the development of education in Ukraine until 2021]. Retrieved from http://osvita.ua/legislation/other/36322/ [in Ukrainian].

Petrovskij, А. (Ed.). (1990). Psihologija. Slovar' [Психология. Словарь]. Moskva: Politizdat [in Russian].

Pro vyshchu osvitu [About higher education]: Zakon Ukrainy. (2014). Retrieved from http://zakon5.rada.gov.ua/laws/show/1556-18 [in Ukrainian].

\section{ESSENCE, STRUCTURE AND FEATURES OF LIFELONG LEARNING COMPETENCE}

Volodymyr Myronenko, postgraduate student of Poltava V. G. Korolenko National Pedagogical University; Valentyna Tytarenko, doctor of Pedagogical Sciences, Full Professor, Dean of the Faculty of Technology and Design of Poltava V. G. Korolenko National Pedagogical University.

The article considers the essence, structure, and features of competence to learn throughout life. To achieve this goal at different stages of scientific research a set of interrelated theoretical methods have been used, which are the following: analysis, classification, generalization of theoretical approaches of national and foreign scientists in the field of philosophy, sociology, pedagogy, and psychology for determining the nature, structure, and features of competence to learn throughout life. The paper aims to reveal the essence of the structure and features of human competence to learn throughout life. The semantic part of the components of the categories "competence», "learning», "human life» as the leading components of the phenomenon "competence to learn throughout life» is characterized. The authors' formulation of the category "competence of lifelong learning» is given. It is considered as the formation of the person's integrative quality, which contains components life maturity, educational orientation, creativity and initiative in solving life situations, a high level of life events) and the formation of personal independence. The basic levels of lifelong learning competence formation are considered: primary, adaptation to the conditions of real-life activity, formation of individual style of educational activity, and ascent to the peaks of professionalism. It is proved that student youth achieve optimal levels of life development due to the formation of the individual's life maturity and independence. Aspects of integration of conceptual and technological bases of preparation of the future teacher of labor training and technologies for the formation of pupils' competence to learn throughout life in the educational environment of the institutions of general secondary education are outlined.

Keywords: student youth, education, competence, lifelong learning, life maturity. 